\title{
FATWA MUI TENTANG PENGURUSAN JENAZAH MUSLIM YANG TERINFEKSI COVID-19 DITINJAU DARI PERSPEKTIF MAZHAB SYĀFI'I
}

\begin{tabular}{|c|c|}
\hline \multicolumn{2}{|c|}{$\begin{array}{c}\text { Ayyub Subandi } \\
\text { Sekolah Tinggi Ilmu Islam dan Bahasa Arab (STIBA) Makassar } \\
\text { Email: ayyubsoebandi@stiba.ac.id }\end{array}$} \\
\hline \multicolumn{2}{|c|}{$\begin{array}{c}\text { Saifullah bin Anshor } \\
\text { Sekolah Tinggi Ilmu Islam dan Bahasa Arab (STIBA) Makassar } \\
\text { Email: saifullah@stiba.ac.id }\end{array}$} \\
\hline Keywords: & $A B S T R A C T$ \\
\hline $\begin{array}{l}\text { Fatwa, MUI, School, } \\
\text { Shafi'i, and Covid-19 }\end{array}$ & $\begin{array}{l}\text { This study aimed at analyzing the fatwa of the Indonesian } \\
\text { Council of Ulama (MUI) regarding the management of Muslim } \\
\text { dead body infected with Covid-19 regarding the Shafi'i School. } \\
\text { This research used descriptive qualitative approach with content } \\
\text { analysis techniques and library research. The results showed that } \\
\text { the fatwa of MUI regarding the management of Muslim dead } \\
\text { body infected with Covid-19 in general had been conducted in } \\
\text { accordance with the established fiqh of Shafi'i School, even } \\
\text { based on the agreement of the four schools. }\end{array}$ \\
\hline Kata kunci: & ABSTRAK \\
\hline $\begin{array}{l}\text { Fatwa, MUI, Mazhab, } \\
\text { Syafi'i, dan Covid-19 }\end{array}$ & $\begin{array}{l}\text { Penelitian ini bertujuan untuk menganalisis fatwa Majelis Ulama } \\
\text { Indonesia (MUI) tentang pengurusan jenazah muslim yang } \\
\text { terinfeksi Covid-19 ditinjau dari Mazhab Syafi'i. Penelitian ini } \\
\text { menggunakan metode pendekatan kualitatif deskriptif dengan } \\
\text { teknik content analysis (analisis isi) dan riset kepustakaan } \\
\text { (library research). Hasil penelitian menunjukkan bahwa fatwa } \\
\text { MUI tentang pengurusan jenazah muslim yang terinfeksi Covid- } \\
19 \text { secara umum sudah dilaksanakan sesuai dengan fikih Mazhab } \\
\text { Syafi'i yang muktamad, bahkan berdasarkan kesepakatan } 4 \\
\text { (empat) mazhab. }\end{array}$ \\
\hline
\end{tabular}

\section{PENDAHULUAN}

Wabah virus corona (Covid-19) menjangkiti hampir seluruh negara, termasuk di antaranya adalah Indonesia. Berdasarkan data Gugus Tugas Percepatan Penanganan Covid-19 hingga Rabu (6/5/2020), sebanyak 12.071 orang positif terinfeksi, 2.197 orang yang berhasil sembuh, sementara 872 
lainnya meninggal dunia akibat serangan virus ini. ${ }^{1}$ Melihat banyaknya korban yang terus berjatuhan, sedangkan virus ini bisa menular jika tidak disikapi dengan tepat, ${ }^{2}$ maka perlu adanya pedoman bagi umat Islam dalam menangani pengurusan jenazah korban yang terinfeksi Covid-19 ini.

Islam sebagai agama sempurna dan paripurna, telah mengatur secara detail dalam buku-buku fikih tentang pengurusan jenazah mulai dari memandikan, mengafani, menyalati, sampai proses penguburan. Fikih Islam juga terus berkembangan mengikuti zaman, sebab 4 (empat) mazhab yang eksis sampai hari ini, Hanafí, Mālikì, Syāfi' 'i, dan Hanbali, masing-masing mempunyai kaidah baku sebagai pedoman, utamanya dalam menyikapi setiap permasalahan kontemporer yang terjadi sebagaimana wabah Covid-19 ini. Melihat perkembangan kematian akibat virus ini yang kunjung belum turun, maka Majelis Ulama Indonesia (MUI) telah mengeluarkan pedoman resmi mengenai pengurusan jenazah muslim yang terinfeksi Covid-19. ${ }^{3}$

Indonesia sebagai negara yang mayoritas penduduknya mengamalkan fikih mazhab syāfi' 'i. ${ }^{4}$ Pertanyaan yang mungkin timbul, apakah pedoman itu berdasarkan fikih mazhab syāfi'i atau tidak?, maka tulisan ini mencoba menjawab pertanyaan tersebut dengan beberapa rincian hukum dalam fikih mazhab Syāfi'i.

Penelitian ini menggunakan metode pendekatan kualitatif deskriptif. Metode tersebut merupakan upaya memahami berbagai konsep yang ditemukan dalam proses penelitian, dengan menggunakan teknik content analysis (analisis isi) dan riset kepustakaan (library research). Teknik content analysis merupakan metode penelitian yang digunakan untuk mengetahui simpulan dari sebuah teks. Dengan kata lain, analisis isi merupakan metode penelitian yang ingin mengungkap gagasan penulis yang termanifestasi maupun yang laten. Sedangkan riset kepustakaan (library research) pada penelitian ini menggunakan jenis dan sumber data sekunder yang diperoleh dari hasil penelitian, artikel dan buku-buku

${ }^{1}$ Lihat: Gugus Tugas Percepatan Penanganan Covid-19, “Data Sebaran”, Situs Resmi Gugus Tugas Percepatan Penanganan Covid-19. https://covid19.go.id/ (Diakses 6 Mei 2020).

${ }^{2}$ Lihat: World Health Organization, "Pertanyaan Dan Jawaban Terkait Coronavirus", Situs Resmi World Health Organization. https://www.who.int/indonesia/news/novel-coronavirus/qa-for-public (Diakses 6 Mei 2020).

${ }^{3}$ Lihat: Majelis Ulama Indonesia, "Fatwa No 18 Tahun 2020 Pedoman Pengurusan Jenazah (Tajhiz al-Janaiz) Muslim Yang Terinfeksi Covid-19”, Situs Resmi Majelis Ulama Indonesia. https://mui.or.id/produk/fatwa/27752/fatwa-no-18-tahun-2020-pedoman-pengurusan-jenazah-tajhiz-aljanaiz-muslim-yang-terinfeksi-covid-19/ (Diakses 6 Mei 2020).

${ }^{4}$ Lihat: Republika, “Alasan Indonesia Bermazhab Syafii Menurut Petualang Maroko”, Situs Resmi Republika. https://khazanah.republika.co.id/berita/q5m809320/alasan-indonesia-bermazhab-syafii-menurutpetualang-maroko (Diakses 6 Mei 2020). 
BUSTANUL FUQAHA: Jurnal Bidang Hukum Islam

Vol. 1, No. 2 (2020) Special Issue : Islamic Law Perspective on Covid-19: Hal. 235-250

Website: https://journal.stiba.ac.id

referensi yang membahas topik yang berkaitan dengan masalah (tema) penelitian. ${ }^{5}$

\section{PEMBAHASAN}

Berikut ini Lampiran Fatwa Majelis Ulama Indonesia nomor: 18 Tahun 2020 tentang Pedoman Pengurusan Jenazah (Tajhỉz al-Janā'iz) Muslim yang Terinfeksi Covid-19 disertai rincian hukum berdasarkan fikih mazhab syāfi'ì.

\section{Ketentuan Umum}

1. Petugas adalah petugas muslim yang melaksanakan pengurusan jenazah.

2. Syahid akhirat adalah muslim yang meninggal dunia karena kondisi tertentu (antara lain karena wabah [tha'un], tenggelam, terbakar, dan melahirkan), yang secara syar'i dihukumi dan mendapat pahala syahid (dosanya diampuni dan dimasukkan ke surga tanpa hisab), tetapi secara duniawi hak-hak jenazahnya tetap wajib dipenuhi.

Maksudnya, perkara ini hukumnya wajib bagi muslim yang masih hidup. Ulama Syafi'iyyah menetapkan kewajiban itu bersifat kolektif; fardu kifayah jika kematiannya diketahui oleh dua orang muslim atau lebih, namun jika kematiannya hanya diketahui oleh satu orang saja, maka hukumnya fardu ain. Imam al-Syāfi’’i ra. menjelaskan:

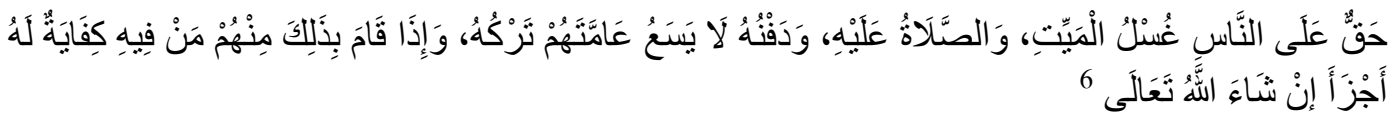

Artinya:

"Merupakan hak wajib seseorang (muslim) atas manusia lainnya adalah memandikan mayit, mensalatinya, dan menguburkannya, meski kewajiban ini tidak berlaku bagi semua orang. Jika sudah ada orang yang melakukannya, maka hal itu sudah cukup (menggugurkan) bagi kewajiban sebagian lainnya, insyaAllah Ta'ala.”

Imam al-Nawawi ra., salah satu ulama otoritatif dari kalangan Mazhab Syāfi' 'ì, menjelaskan:

\footnotetext{
${ }^{5}$ Azwar Iskandar dan Khaerul Aqbar, Kedudukan Ilmu Ekonomi Islam di Antara Ilmu Ekonomi dan Fikih Muamalah: Analisis Problematika Epistemologis, Nukhbatul 'Ulum: Jurnal Bidang Kajian Islam, Vol. 5, No. 2 (2019), h. 88-105. https://journal.stiba.ac.id/index.php/nukhbah/article/view/77.

${ }^{6}$ Muhammad ibn Idrīs al-Syāfi' ’’, Al-Um, Juz 1 (Cet. I; Beirut: Dār al-Ma'rifah, 1410 H/1990 M), h.312.
} 


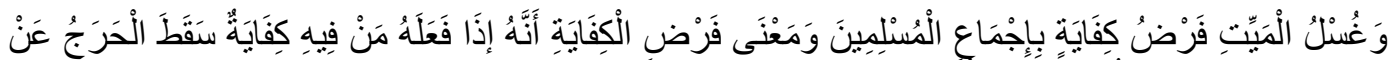

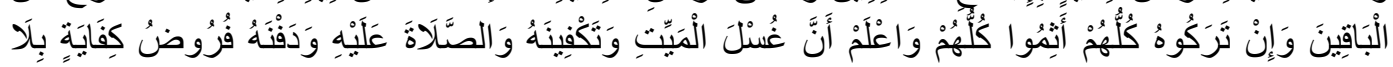

Artinya:

"Memandikan mayat adalah fardu kifayah berdasarkan ijmak kaum muslimin. Makna fardu kifayah ini adalah bahwa bila sudah ada seseorang yang melakukannya, maka gugur tanggungan bagi yang lain. Namun, jika sama sekali tidak ada yang melakukannya, maka semuanya berdosa. Ketahuilah, sesungguhnya memandikan mayat, mengafaninya, mensalatinya adalah fardu kifayah, tanpa adanya khilāf (perbedaan pendapat)."

Namun, sekiranya tidak ada seorang pun muslim yang memandikannya, kemudian ada non muslim yang memandikannya, maka hal itu sudah dianggap cukup, karena non muslim termasuk mukalaf dalam masalah furū'. Begini penjelasan Imam al-Nawawi ra.:

$$
\text { و لا تجب نية الغاسل في الأصح فيكفي غرقه أو غسل كافر^ }
$$

Artinya:

"Orang yang memandikan tidak wajib berniat menurut pendapat yang ashah (paling benar dalam mazhab syāfi'ì), maka cukup dibenamkan ke dalam air atau dimandikan oleh orang kafir."

Ibn Hajar al-Haitamī ra. memperjelas alasannya:

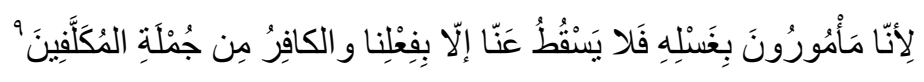

Artinya:

"Karena kita (muslim) diperintahkan memandikannya, maka tidak gugur (kewajiban itu) dari kita kecuali dengan perbuatan kita, (begitu juga) denga orang kafir termasuk mukalaf."

3. APD (Alat Pelindung Diri) adalah alat pelindung diri yang digunakan oleh petugas yang melaksanakan pengurusan jenazah.

\footnotetext{
${ }^{7}$ Yahya ibn Syaraf al-Nawawī, Al-Majmū' Syarah al-Muhażżab, Juz 5 (Cet. II; al-Riyadh: Dār 'Ālam al-Kutub, 1427 H/2006 M), h.81.

${ }^{8}$ Yahya ibn Syaraf al-Nawawi, Minhāj al-Ṭălibīn wa 'Umdah al-Muftīn, Juz 1 (Cet. IV; Beirut: Dār al-Basyā'ir al-Islāmiyah, $1432 \mathrm{H} / 2011 \mathrm{M})$, h.323.

${ }^{9}$ Ahmad ibn Ahmad ibn Ali ibn Hajar al-Haitami, Tuhfah al-Muhtaj fi Syarh al-Minhaj wa Hawasyi al-Syarwani wa al-Abbadi, Juz 3 (Beirut: Dar al-Fikr, 1432 H/1431 M), h.109.
} 
Dalam menjalankan tugas, sangat dianjurkan agar melaksanakannya dengan professional dengan tetap memperhatikan keselamatan. Hal ini sebagaimana firman Allah Ta'ala,

Terjemahnya:

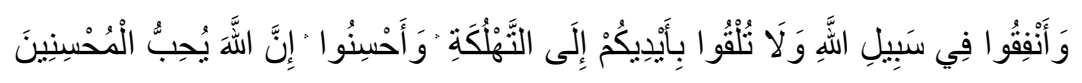

"Dan janganlah kamu jatuhkan (diri sendiri) ke dalam kebinasaan dengan tangan sendiri, dan berbuatbaiklah. Sungguh, Allah menyukai orangorang yang berbuat baik." (Q.S. Al-Baqarah/2: 195).

Malik ra. dan lainnya meriwayatkan hadis Yahya al-Māzinī ra., Nabi shallallahu 'alaihi wasallam bersabda dengan sanad yang hasan:

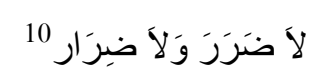

Artinya:

"Tidak (boleh) membahayakan (diri sendiri atau orang lain)."

Dalam hadis yang lain riwayat al-Baihaqi dari 'Āisyah ra., Rasulullah shallallahu 'alaihi wasallam bersabda:

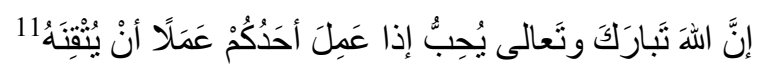

Artinya:

"Sesungguhnya Allah tabāraka wa ta'āla mencintai jika seorang diantara kalian professional dalam menjalankan perkerjaannya."

\section{Ketentuan Hukum}

1. Menegaskan kembali Ketentuan Fatwa MUI Nomor 14 Tahun 2020 angka 7 yang menetapkan: "Pengurusan jenazah (tajhiz al-jana'iz) yang terpapar Covid-19, terutama dalam memandikan dan mengafani harus dilakukan sesuai protokol medis dan dilakukan oleh pihak yang berwenang, dengan tetap memperhatikan ketentuan syariat. Sedangkan untuk menyalatkan dan menguburkannya dilakukan sebagaimana biasa dengan tetap menjaga agar tidak terjangkit Covid-19."

${ }^{10}$ Mālik ibn Anas, al-Muwatța', Juz 4 (Cet. I; Abū Dhabī: Mu'assasah Zā'yid ibn Sulțān Ālu Nahyān li al-A'māl al-Khairiyah wa al-Insaniyah, 1425 H/2004 M), h.1078., Muhammad ibn Yazìd alQazwīnī, Sunan Ibn Mājah, Juz 2 (t.t.p. Dār Ihyā' al-Kutub al-Arabiyah, t.th), h.784., Muhammad ibn Abdullah al-Hākim, Mustadrak 'ala al-Sahihain, Juz 2 (Cet. I; Beirut: Dar al-Kutub al-Ilmiyah, 1411 H/1990 M), h.66.

${ }^{11}$ Ahmad ibn al-Husein al-Baihaqi, Syu'ab al-İman, Juz 7 (Cet. I; Al-Riyadh: Maktabah al-Rusyd, 1423 H/2003 M), h. 232. 
BUSTANUL FUQAHA: Jurnal Bidang Hukum Islam

Vol. 1, No. 2 (2020) Special Issue : Islamic Law Perspective on Covid-19: Hal. 235-250

Website: https://journal.stiba.ac.id

Hal ini berdasarkan kaidah fikih yang berbunyi:

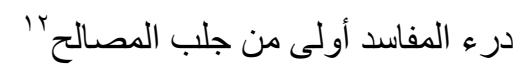

Artinya:

"Mencegah mafsadat (kerusakan) harus didahulukan daripada mengambil kemaslahatan."

Sedangkan kaidah ini berangkat dari hadis Abu Hurairah ra. riwayat alBukhari ra., Nabi shallallahu 'alaihi wasallam bersabda:

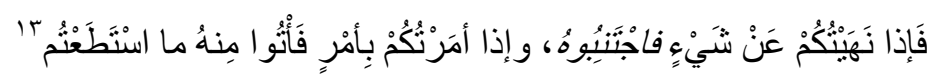

Artinya:

"Jika aku melarangmu untuk meninggalkan sesuatu, maka tinggalkanlah.

Jika aku memerintahkanmu untuk melakukan sesuatu, maka lakukanlah sesuai kesanggupanmu."

Jika menelaah dalil-dalil dan kaidah di atas, maka dapat disimpulkan bahwa dalam kondisi harus memilih antara keselamatan petugas yang masih hidup dan sehat dengan jenazah pasien Covid-19, menurut standar prioritas, maka menjamin keselamatan petugas lebih utama.

2. Umat Islam yang wafat karena wabah Covid-19 dalam pandangan syara' termasuk kategori syahid akhirat dan hak-hak jenazahnya wajib dipenuhi, yaitu dimandikan, dikafani, disalati, dan dikuburkan, yang pelaksanaannya wajib menjaga keselamatan petugas dengan mematuhi ketentuan-ketentuan protokol medis.

Dikecualikan kategori syahid dunia dan akhirat, yaitu yang meninggal dalam peperangan melawan orang kafir di medan jihad, maka tidak dimandikan. ${ }^{14}$

\section{Pedoman Memandikan Jenazah yang Terpapar Covid-19 Dilakukan Sebagai Berikut:}

1) Jenazah dimandikan tanpa harus dibuka pakaiannya.

\footnotetext{
${ }^{12}$ Abd al-Raḥmān ibn Abu Bakr al-Suyūî̀, al-Asybāḥ wa al-Nazā'ir (Cet. I; Beirut: Dār al-Kutub al-Ilmiyah, $1411 \mathrm{H} / 1990 \mathrm{M})$, h.87.

${ }^{13}$ Muhammad ibn Ismà'ìl al-Bukhārì, al-Jāmi' al-Musnad al-Sahīh al-Muktashar min Umūr Rasūlillāh saw. wa Sunanih wa Ayyamih, Juz 9 (Cet. I: Dār Ṭ̂uq al-Najāh, 1422 H), h.94.

${ }^{14}$ Lihat: Muhammad ibn Ahmad al-Khatib al-Syirbini, al-Iqnā' fí Hilli Alfaz Abī Syujā', Juz 1 (Cet. I; Damaskus: Maktabah Dār al-Fajr, 1436 H/2015 M), h.421.
} 
Dalam Mazhab Syāfi'‘ sendiri, membuka pakaian jenazah ketika dimandikan tidak wajib, justru sebaliknya; disunahkan agar dimandikan menggunakan pakaian atau ditutupi dengan kain tipis, dengan alasan supaya auratnya terjaga. Berikut penjelasan Imam al-Nawawi ra.:

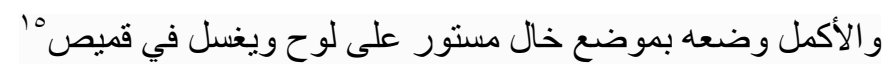

Artinya:

"(Cara) sempurnanya, ditempatkan di ruang yang kosong dan tertutup oleh dinding kemudian dimandikan (dalam keadaan) tertutup kain."

Hal ini berdasarkan penuturan Buraidah ra. riwayat Ibn Mājah, beliau menceritakan:

Artinya:

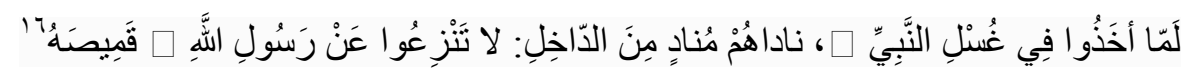

"Ketika Rasulullah saw. hendak dimandikan, tiba-tiba ada peringatan dari dalam, 'Jangan tanggalkan pakaian Rasulullah saw.!'”

2) Petugas wajib berjenis kelamin yang sama dengan jenazah yang dimandikan dan dikafani;

3) Jika petugas yang memandikan tidak ada yang berjenis kelamin sama, maka dimandikan oleh petugas yang ada, dengan syarat jenazah dimandikan tetap memakai pakaian. Jika tidak, maka ditayamumkan.

Berdasarkan kedua poin di atas, berikut penjelasan Imam al-Nawawi ra.:

$$
\text { وإيغسل الرجل الرجل أجنبية والمر أن المر أة ويغسل أمته وزوجته وهي زوجها ويلفان خرقة ولا مس فإن لم يحضر }
$$

Artinya:

"Laki-laki memandikan (jenazah) laki-laki, wanita memandikan (jenazah) wanita, laki-laki memandikan (jenazah) ibunya, (jenazah) istrinya, begitu juga wanita memandikan (jenazah) suaminya, mereka berdua (laki-laki dan wanita) memandikan pasangannya dengan melilitkan kain (pada tangan) dan tidak menyentuh (kulitnya). Namun, jika tidak ada kecuali

\footnotetext{
${ }^{15}$ Yahya ibn Syaraf al-Nawawi, Minhäj al-Ṭălibīn wa 'Umdah al-Muftīn, Juz 1, h.323324.

${ }^{16}$ Muhammad ibn Yazīd al-Qazwīini, Sunan Ibn Mājah, Juz 1, h.471., Muhammad ibn Abdullah al-Hākim, Mustadrak 'ala al-Sahihain, Juz 1, h.505.

${ }^{17}$ Yahya ibn Syaraf al-Nawawi, Minhāj al-Tạalibīn wa 'Umdah al-Muftīin, Juz 1, h.327.
} 
BUSTANUL FUQAHA: Jurnal Bidang Hukum Islam

Vol. 1, No. 2 (2020) Special Issue : Islamic Law Perspective on Covid-19: Hal. 235-250

Website: https://journal.stiba.ac.id

laki-laki atau wanita ajnabī (bukan mahram), maka cukup ditayamumkan."

4) Petugas membersihkan najis (jika ada) sebelum memandikan;

5) Petugas memandikan jenazah dengan cara mengucurkan air secara merata ke seluruh tubuh;

Ketika memandikan jenazah, ada cara sempurna dan ada cara minimal. Cara sempurna dilakukan jika keadaan memungkinkan sebagaimana biasanya, namun jika tidak memungkinkan; seperti khawatir tertular virus covid-19, maka cukup melakukan cara yang minimal sebagaimana kedua poin di atas. Hal ini juga dijelaskan oleh Imam al-Nawawi ra.:

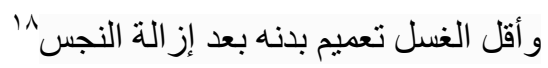

Artinya:

"Minimal (cara) memandikan (jenazah) adalah siraman yang menyeluruh badan setelah menghilangkan najis."

Sebab, jika keharusan menghilangkan najis ketika mandi wajib berlaku untuk orang yang masih hidup, maka begitu juga ketika memandikan jenazah.

6) Jika atas pertimbangan ahli yang terpercaya bahwa jenazah tidak mungkin dimandikan, maka dapat diganti dengan tayamum sesuai ketentuan syariat, yaitu dengan cara:

a) Mengusap wajah dan kedua tangan jenazah (minimal sampai pergelangan) dengan debu.

b) Untuk kepentingan perlindungan diri pada saat mengusap, petugas tetap menggunakan APD.

Berikut menurut Ibn Ḥajar al-Haitamī ra.:

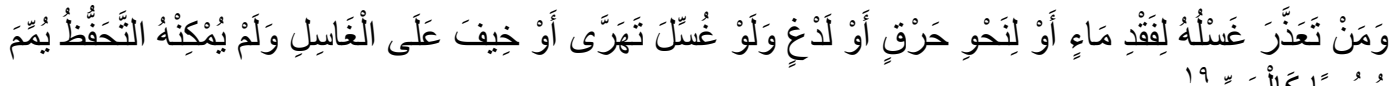

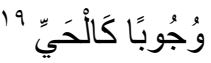

Artinya:

"Jenazah manapun yang tidak memungkinkan untuk dimandikan disebabkan karena ketiadaan air, atau karena korban kebakaran, atau gigitan ular, yang dimana jika dimandikan maka akan terkoyak, atau

\footnotetext{
${ }^{18}$ Yahya ibn Syaraf al-Nawawi, Minhāj al-Ṭălibīn wa 'Umdah al-Muftīn, Juz 1, h.323.

${ }^{19}$ Ahmad ibn Ahmad ibn Ali ibn Hajar al-Haitami, Tuhfah al-Muhtaj fi Syarh al-Minhaj wa Hawasyi al-Syarwani wa al-Abbadi, Juz 3, h.202.
} 
dikhawatirkan bahaya atas orang yang memandikan dimana sulit baginya untuk terjaga dari bahaya itu, maka wajib ditayamumkan sebagaimana tayamumnya orang yang masih hidup."

7) Jika menurut pendapat ahli yang terpercaya bahwa memandikan atau menayamumkan tidak mungkin dilakukan karena membahayakan petugas, maka berdasarkan ketentuan darurat syar'iyyah, jenazah tidak dimandikan atau ditayamumkan.

Jika tidak bisa tayamum karena tetap khawatir tertular virusnya, maka langsung dimakamkan saja tanpa dimandikan dan tanpa dikafani berdasarkan pendapat muktamad dalam Mazhab Syāfi' 'i, karena memandikan dan mengafani jenazah adalah syarat sah menyalatinya. Sedangkan menurut sebagian ulama Syafi'iyah tetap disalati.

Berikut penjelasan Al-Haitami ra.:

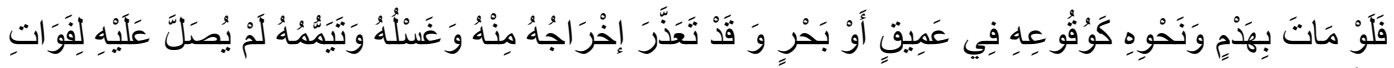

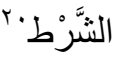

Artinya:

"Jika jenazah itu meninggal disebabkan benturan atau semisalnya, seperti terjatuh di dalam jurang yang dalam, atau tenggelam di lautan, kemudian sulit diangkat (dari jurang atau dalam laut) sehingga tidak bisa dimandikan dan ditayamumkan, maka (jenazah itu) tidak disalati, karena syarat (sahnya) tidak terpenuhi (tidak dimandikan dan tidak dikafani).“

Namun, menurut al-Khatīb al-Syarbīni ra., jenazah itu tetap disalati walaupun tidak dimandikan dan dikafani, berikut penjelasan beliau:

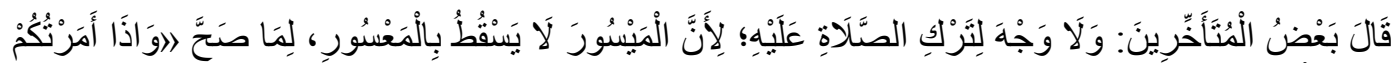

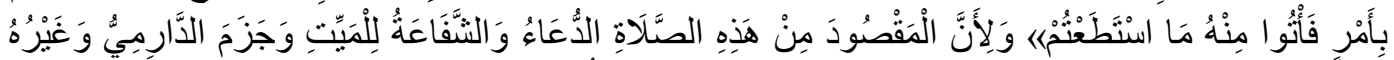

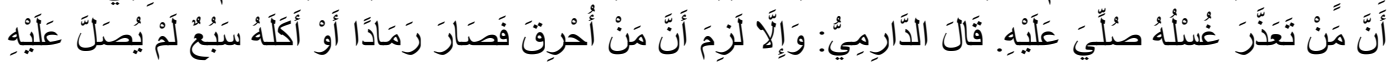

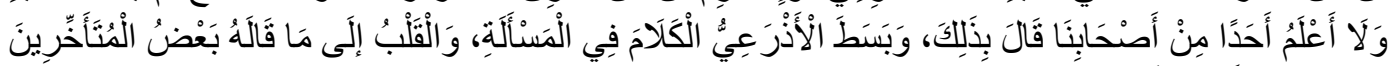

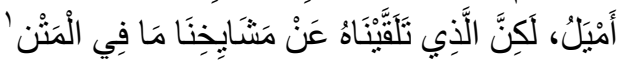

Artinya:

"Sebagian ulama (Syafi'iyah) muta'akkhirīn berpendapat, tidak ada alasan untuk tidak menyalatinya, sebab perkara yang mudah (dilakukan)

\footnotetext{
${ }^{20}$ Ahmad ibn Ahmad ibn Ali ibn Hajar al-Haitami, Tuhfah al-Muhtaj fi Syarh al-Minhaj wa Hawasyi al-Syarwani wa al-Abbadi, Juz 3, h.208.

${ }^{21}$ Muhammad ibn Aḥmad al-Khatīb al-Syarbinī, Mugnī al-Muhtāj ila Ma'rifah Ma'ānì Alfäz alMinhājj, Juz 2 (Cet. I; Beirut: Dār al-Kutub al-Ilmiyah, 1415 H/1994 M), h.50.
} 
tidak gugur disebabkan karena alasan kesulitan, hal ini berdasarkan (hadis) sahih "Jika aku perintahkan sesuatu atas kalian, maka lakukanlah semampunya." Juga karena alasan salat adalah doa dan syafaat atas si mayat. Al-Dārimi dan lainnya juga memastikan bahwa jenazah yang tidak memungkinkan untuk dimandikan, maka tetap disalati. Beliau (al-Dārimī) mengatakan: "Sekiranya (jenazah yang tidak dimandikan, tidak perlu disalati) maka seharusnya mayat korban kebakaran yang sudah jadi abu dan atau dimakan hewan buas juga tidak perlu disalati, namun saya tidak menemukan pendapat seperti ini dari ashabuna (ulama Syafi'iyah). AlAżra'i juga membahas panjang masalah ini. Akan tetapi hati saya (alSyarbīnī) lebih condong kepada pendapat sebagian muta'akkhirin, walaupun yang kami pelajari dari guru-guru kami sebagaimana disebutkan dalam matan (Minhāj al-Thālibīn karya al-Nawawi).”

Al-Syarwānī ra. juga mengarahkan agar mengikuti pendapat sebagaian ulama muta'akkhirīn itu, sebagai tindakan menghargai jenazah dan menjaga perasaan keluargannya, berikut penjelasan beliau:

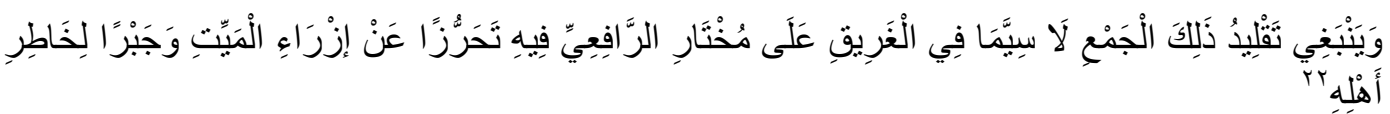

Artinya:

“Selayaknya mengikuti sebagaian ulama muta'akkhirin itu, apatah lagi jika jenazahnya tenggelam sebagaimana pendapat al-Rāfi' $\bar{i}$, sebagai tindakan tidak menyia-nyiakan jenazah dan menjaga perasaan keluarganya."

\section{Pedoman Mengafani Jenazah yang Terinfeksi Covid-19 Dilakukan Sebagai Berikut:}

1) Setelah jenazah dimandikan atau ditayamumkan, atau karena dharurah syar'iyah tidak dimandikan atau ditayamumkan, maka jenazah dikafani dengan menggunakan kain yang menutup seluruh tubuh dan dimasukkan ke dalam kantong jenazah yang aman dan tidak tembus air untuk mencegah penyebaran virus dan menjaga keselamatan petugas.

2) Setelah pengafanan selesai, jenazah dimasukkan ke dalam peti jenazah yang tidak tembus air dan udara dengan dimiringkan ke kanan sehingga saat dikuburkan jenazah menghadap ke arah kiblat.

${ }^{22}$ Ahmad ibn Ahmad ibn Ali ibn Hajar al-Haitami, Tuhfah al-Muhtaj fi Syarh al-Minhaj wa Hawasyi al-Syarwani wa al-Abbadi, Juz 3, h.208. 
Menurut al-Ramli, menguburkan mayat muslim menggunakan peti hukumnya makruh berdasarkan ijmak, kecuali beberapa keadaan, begini penjelasannya:

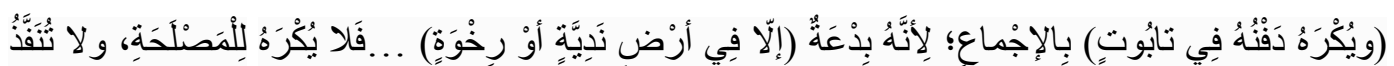

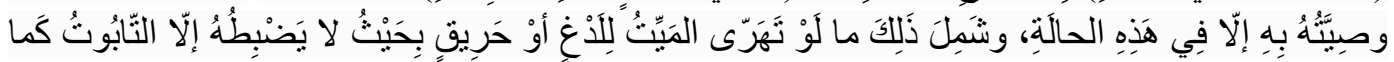

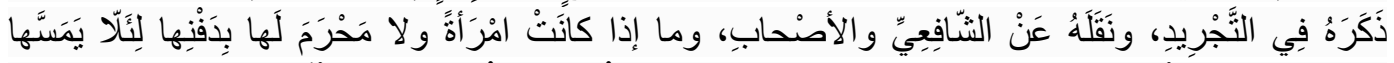

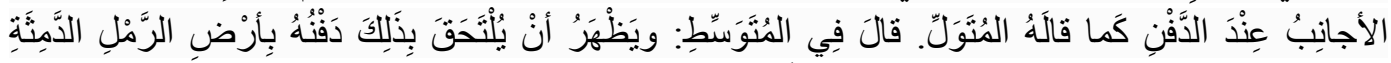

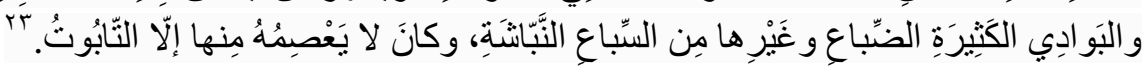

Artinya:

"Dan dimakruhkan mengubur mayat di dalam peti, berdasarkan ijmak ulama karena hal itu dinilai bidah. Kecuali pada tanah yang basah atau sangat lembek, maka tidaklah makruh (mengubur mayat dengan peti pada tanah tersebut) karena maslahat, walaupun mayat sendiri berwasiat demikian maka juga tidak (wajib) dipenuhi kecuali jika keadaannya seperti itu. Begitu juga apabila keadaan mayat sangat rapuh, karena tersengat atau terbakar yang tidak mungkin mayat bisa utuh kecuali dengan cara dipeti sebagaimana disebutkan dalam (kitab) al-Tadrīj, dinukil pula dari Imam al-Syāfi’’’ dan al-Aṣhāă. Begitu juga jika mayat adalah perempuan dan tidak ada mahramnya yang menguburkannya (sehingga yang tersisa adalah orang lain) maka mayat boleh dipeti agar mereka tidak menyentuhnya ketika proses penguburan sebagaimana dijelaskan oleh al-Mutawalli. Disebutkan juga dalam (kitab) alMutawassit, tampaknya (termasuk alasan boleh menggunakan peti) jika penguburan di tanah pasir yang lembut, di bawādì yang banyak hiena ${ }^{24}$ dan binatang buas lainnya yang bisa menggali tanah, dimana peti bisa berfungsi melindungi jenazah itu, maka tidaklah makruh."

Demikianlah makruhnya mengubur mayat menggunakan peti yang telah disepakati mayoritas ulama. Kecuali ada alasan tertentu berkaitan dengan maslahat jenazah, maka bisa dipahami bahwa jika maslahatnya berkaitan dengan orang lain, seperti antisipasi penularan virus Covid-19, maka lebih dibolehkan lagi.

3) Jika setelah dikafani masih ditemukan najis pada jenazah, maka petugas dapat mengabaikan najis tersebut.

\footnotetext{
${ }^{23}$ Muhammad ibn Abū al-Abbās Syams al-Dīn al-Ramli, Nihāyah al-Muḥtāj ilā Syarh al-Minhājo, Juz 3 (Cet. I; Beirut: Dar al-Fikr, 1404 H/1984 M), h.30.

${ }^{24}$ Sejenis anjing hutang pemakan bangkai dan daging (Lih. Kamus Besar Bahasa Indonesia).
} 
BUSTANUL FUQAHA: Jurnal Bidang Hukum Islam

Vol. 1, No. 2 (2020) Special Issue : Islamic Law Perspective on Covid-19: Hal. 235-250

Website: https://journal.stiba.ac.id

Sebab agama ini dibangun di atas kemudahan, syariatnya tidak membebankan melebihi kemampuan seseorang. Allah Ta'ala berfirman:

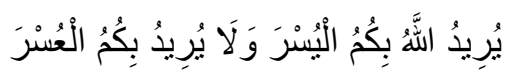

Terjemahnya:

"Allah menghendaki kemudahan bagimu, dan tidak menghendaki kesukaran bagimu." (Q.S. Al-Baqarah/2: 185).

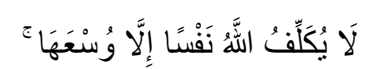

Terjemahnya:

"Allah tidak membebani seseorang melainkan sesuai dengan kesanggupannya.” (Q.S. Al-Baqarah/2: 286).

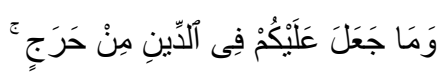

Terjemahannya:

"Dia tidak menjadikan kesukaran untukmu dalam agama." (Q.S. AlHajj/22: 78).

Pedoman Menyalatkan Jenazah yang Terpapar Covid-19 Dilakukan Sebagai Berikut:

1) Disunahkan menyegerakan salat jenazah setelah dikafani.

Hal ini berdasarkan hadis Abu Hurairah ra. riwayat al-Bukhārì ra., Rasulullah shallallahu 'alaihi wasallam bersabda:

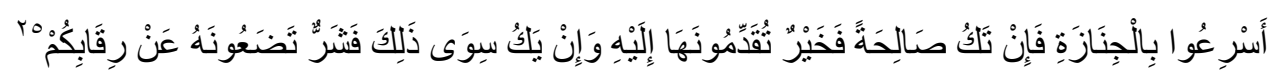

Artinya:

"Segeralah kalian menguburkan jenazah. Jika jenazah itu baik, maka kalian telah mendekatkanya pada kebaikan. Jika jenazah itu buruk, maka kalian telah melepaskan dari pundak kalian."

2) Dilakukan di tempat yang aman dari penularan Covid-19.

3) Dilakukan oleh umat Islam secara langsung (hadir) minimal 1 (satu) orang. Jika tidak memungkinkan, boleh disalatkan di kuburan sebelum atau

\footnotetext{
${ }^{25}$ Muhammad ibn Ismā'ìl al-Bukhārī, al-Jāmi' al-Musnad al-Sahīh al-Muktashar min Umūr Rasūlillāh saw. wa Sunanih wa Ayyamih, Juz 2, h.86.
} 
BUSTANUL FUQAHA: Jurnal Bidang Hukum Islam

Vol. 1, No. 2 (2020) Special Issue : Islamic Law Perspective on Covid-19: Hal. 235-250

Website: https://journal.stiba.ac.id

sesudah dimakamkan. Jika tidak dimungkinkan, maka boleh disalatkan dari jauh (salat ghaib).

4) Pihak yang menyalatkan wajib menjaga diri dari penularan Covid-19.

Ketiga poin di atas terhimpun dalam kaidah fikih berikut yang berbunyi:

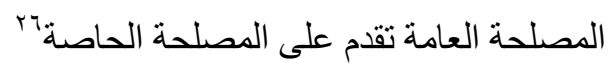

Artinya:

"Maslahat umum lebih diutamakan daripada maslahat pribadi"

Dimana menjaga lingkungan sekitar agar tidak tertular virus lebih didahulukan daripada maslahat yang sifatnya pribadi.

\section{Pedoman Menguburkan Jenazah yang Terpapar Covid-19 Dilakukan Sebagai Berikut:}

1) Dilakukan sesuai dengan ketentuan syariat dan protokol medis.

Sebab ketika urusan diamanahkan kepada orang yang bukan ahlinya, maka justru akan berakibat fatal. Al-Bukhāri ra. meriwayatkan hadis Abu Hurairah ra., Rasulullah shallallahu 'alaihi wasallam bersabda:

Artinya:

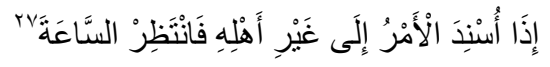

"Jika urusan diserahkan bukan kepada ahlinya, maka tunggulah kehancuran itu."

2) Dilakukan dengan cara memasukkan jenazah bersama petinya ke dalam liang kubur tanpa harus membuka peti, plastik, dan kafan.

Karena jika dibuka, dikhawatirkan membahayakan petugas kesehatan (Nakes) dan masyarakat sekitar pekuburan, sehingga cara seperti ini dipandang sebagai suatu hajat. Berkaitan dengannya sebuah kaidah fikih berbunyi:

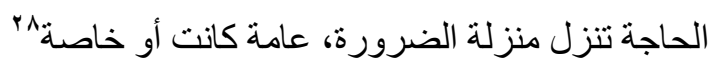

Artinya:

\footnotetext{
${ }^{26}$ Muhammad al-Zuhaili, Al-Qawā'id al-Fiqhiyyah wa Tatbīqātiha fi al-Mazhab al-Syafi'i, Juz 2 (Cet. I; Damaskus: Dār al-Ifhàंm, 1440 H/2019 M), h.22.

${ }^{27}$ Muhammad ibn Ismā'îl al-Bukhārí, al-Jāmi’ al-Musnad al-Sahīh al-Muktashar min Umūr Rasūlillāh saw. wa Sunanih wa Ayyamih, Juz 8, h.104.

${ }^{28}$ Muhammad al-Zuhaili, Al-Qawā'id al-Fiqhiyyah wa Tatbīqātiha fi al-Mazhab al-Syafi 'î, Juz 2, h.77.
} 
BUSTANUL FUQAHA: Jurnal Bidang Hukum Islam

Vol. 1, No. 2 (2020) Special Issue : Islamic Law Perspective on Covid-19: Hal. 235-250

Website: https://journal.stiba.ac.id

"Hajat bisa digolongkan darurat, baik hajat umum atau khusus."

3) Penguburan beberapa jenazah dalam satu liang kubur dibolehkan karena darurat (al-dharurah al-syar'iyyah) sebagaimana diatur dalam ketentuan fatwa MUI nomor 34 tahun 2004 tentang Pengurusan Jenazah (Tajhiz alJana'iz) Dalam Keadaan Darurat.

Pada dasarnya, liang kubur hanya untuk satu jenazah saja. Namun, disebabkan karena kondisi darurat maka ada pengecualian. Hal ini dikuatkan satu kaidah fikih, yaitu:

Artinya:

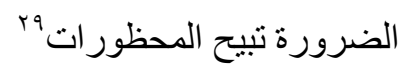

"Darurat membolehkan perbuatan yang dilarang."

\section{KESIMPULAN}

Berdasarkan pemaparan di atas, penulis menyimpulkan bahwa fatwa MUI tentang pengurusan jenazah muslim yang terinfeksi Covid-19 secara umum sudah berdasarkan fikih Mazhab Syāfi'ì yang muktamad, bahkan berdasarkan kesepakatan 4 mazhab. Sebab kebanyakan permasalahannya berkisar pada qawaid fikih tentang maslahat mudarat, darurat, dan taisir (memudahkan), dimana biasanya menghasilkan hukum yang disepakati oleh semua ulama dan tidak terkhusus pada mazhab tertentu saja.

\section{DAFTAR PUSTAKA}

. (1432 H/2011 M). Minhāj al-Ṭālibīn wa 'Umdah al-Muftīn. Cetakan keempat. Beirut. Dār al-Basyā'ir al-Islāmiyah.

. (1436 H/2015 M). Al-Iqnā' fì Hilli Alfáz Abỉ Syujā'. Cetakan pertama. Damaskus. Maktabah Dār al-Fajr.

Al-Baihaqì, Ahmad ibn al-Husein. (1423 H/2003 M). Syu'ab al-İman. Cetakan pertama. Riyadh. Maktabah al-Rusyd.

Al-Bukhārì, Muhammad ibn Ismā'ìl. (1422 H). Al-Jāmi’ al-Musnad al-Sahīh alMuktashar min Umūr Rasūlillāh saw. wa Sunanih wa Ayyamih. Cetakan pertama. Dār Ṭauq al-Najāh.

${ }^{29}$ Abdullah ibn Sa’ìd al-Lahjī, İdhāh al-Qawā'id al-Fiqhiyyah (Cet. III; Kuwait; Dār al-Dhiyā', $1438 \mathrm{H} / 2017 \mathrm{M})$, h.77. 
Al-Hākim, Muhammad ibn Abdullah. (1411 H/1990 M) Mustadrak 'ala alSahihain. Cetakan pertama. Beirut. Dār al-Kutub al-Ilmiyah.

Al-Haitami, Ahmad ibn Ahmad ibn Ali ibn Hajar. (1432 H/1431 M). Tuhfah alMuhtaj fi Syarh al-Minhaj wa Hawasyi al-Syarwani wa al-Abbadi. Beirut. Dar al-Fikr.

Al-Lahji, Abdullah ibn Sa'id. İdhāh al-Qawā'id al-Fiqhiyyah. Cetakan ketiga. Kuwait. Dār al-Dhiyā'.

Al-Nawawi, Yahya ibn Syaraf. (1427 H/2006 M). Al-Majmū' Syarah alMuhażżab. Cetakan kedua. Riyadh. Dār 'Ālam al-Kutub.

Al-Qur'an.

Al-Ramli, Muḥammad ibn Abū al-Abbās Syams al-Dīn. (1404 H/1984 M). Nihāyah al-Mụ̂tāj ilā Syarh al-Minḥāj. Cetakan pertama. Beirut. Dar alFikr.

Al-Suyūți, Abd al-Raḥmān ibn Abu Bakr. (1411 H/1990 M). Al-Asybāḥ wa alNazā'ir. Cetakan pertama. Beirut: Dār al-Kutub al-Ilmiyah.

Al-Syāfi'ī, Muhammad ibn Idrīs. (1410 H/1990 M). Al-Um. Cetakan pertama, Beirut, Dār al-Ma'rifah.

Al-Syarbīnī, Muḥammad ibn Aḥmad al-Khatīb. Mugnī al-Muḥtāj ila Ma'rifah Ma'ānì Alfāz al-Minhāj, Juz 2 (Cet. I; Beirut: Dār al-Kutub al-Ilmiyah, $1415 \mathrm{H} / 1994 \mathrm{M})$, h.50.

Al-Zuhaili, Muhammad. (1440 H/2019 M). Al-Qawā'id al-Fiqhiyyah wa Tatbīqātiha fi al-Mazhab al-Syafí 'î. Cetakan pertama. Damaskus. Dār alIfhām.

Gugus Tugas Percepatan Penanganan Covid-19. "Data Sebaran." https://covid19.go.id/ (Diakses 6 Mei 2020).

https://covid19.go.id/ (Diakses 6 Mei 2020).

Ibn Majah, Muhammad ibn Yazid al-Qazwīni. Sunan Ibn Mājah. Dār Ihyā' alKutub al-Arabiyah.

Iskandar, A., Aqbar, K. (2019). Kedudukan Ilmu Ekonomi Islam di Antara Ilmu Ekonomi dan Fikih Muamalah: Analisis Problematika Epistemologis. Nukhbatul 'Ulum: Jurnal Bidang Kajian Islam, Vol. 5, No. 2, h. 88-105. https://journal.stiba.ac.id/index.php/nukhbah/article/view/77.

Mālik ibn Anas. al-Muwatța'. (1425 H/2004 M). Cetakan pertama. Abū Dhabī. Mu'assasah Zā'yid ibn Sulțān Ālu Nahyān li al-A'māl al-Khairiyah wa alInsaniyah., h.1078.

MUI. "Fatwa no. 18 Tahun 2020: Pedoman Pengurusan Jenazah Tajhiz Al-Janaiz Muslim yang Terinfeksi Covid-19." https://mui.or.id/produk/fatwa/27752/fatwa-no-18-tahun-2020-pedomanpengurusan-jenazah-tajhiz-al-janaiz-muslim-yang-terinfeksi-covid-19/, (Diakses 6 Mei 2020). 
BUSTANUL FUQAHA: Jurnal Bidang Hukum Islam

Vol. 1, No. 2 (2020) Special Issue : Islamic Law Perspective on Covid-19: Hal. 235-250

Website: https://journal.stiba.ac.id

Nashrullah, N.” Alasan Indonesia Bermazhab Syafii Menurut Petualang Maroko." https://khazanah.republika.co.id/berita/q5m809320/alasan-indonesiabermazhab-syafii-menurut-petualang-maroko, (Diakses 6 Mei 2020).

World Health Organization. "Novel Coronavirus." https://www.who.int/indonesia/news/novel-coronavirus/qa-for-public, (Diakses 6 Mei 2020). 